\title{
Pendampingan pada ibu yang memiliki anak cerebral palsy
}

\author{
$\Psi$ Altruis \\ Journal of Community Services \\ p-ISSN 2721-4168; e-ISSN 2721-415X \\ pISSN 2721-4168; eISSN 2721-415x \\ ejournal.umm.ac.id/index.php/altruis \\ 2021, Vol 2(1):1-4 \\ DOI:10.22219/altruis.v2i1.15871 \\ (C)The Author(s) 2021 \\ (c)(1) $\$ 4.0$ International license
}

\author{
Susanti Prasetyaningrum ${ }^{1}$
}

\begin{abstract}
In almost every stage of their lives, CP children need other people to help them meet their daily needs. For this, the mother is the main person who supports the children. Therefore, mothers must possess sufficient knowledge to satisfy the developmental needs of their children with CP. The purpose of this program was to foster a deeper understanding and transfer critical information related to $\mathrm{CP}$ to mothers with children who have $\mathrm{CP}$. The methods used are experience sharing and psychoeducation. Experience sharing was conducted in groups, where 3 groups are formed. In each group, there were five to eight group members. The group consisted of mothers with CP adolescents, university students, doctors, and psychologists. While psychoeducation was given to mothers who have adolescents with CP and their significant others, namely fathers, grandmothers, grandparents, aunts, or other relatives. The results of this program indicated that the program had proven to be effective in increasing the knowledge of CP among mothers who have children with cerebral palsy regarding the characteristics, potential, and emotional state of children with cerebral palsy. Effectiveness can also be seen from the perceived benefits of the programs in aspects including lessons, facilities, facilitators, and the emotional comfort in assigned groups.
\end{abstract}

\section{Keywords}

Assistance, cerebral palsy, psychoeducation, mothers

\section{Pendahuluan}

Cerebral palsy (CP) adalah jenis gangguan motorik menetap, tidak progresif yang terjadi sebagai karena kerusakan otak akibat trauma lahir atau patologi intra uterine (Soetomenggolo \& Ismael, 1999). Gambaran klinis CP dapat berubah selama hidup dan terjadi sejak usia dini. Menurut Dorland (2005) tanda-tanda dari CP adalah terlambatnya perkembangan motorik, seperti paraplegia spastik, hemiplegia atau tetraplegia yang sering disertai retardasi mental, kejang atau ataksia. Dari berbagai tandatanda diatas dapat disimpulkan bahwa CP merupakan kelainan syaraf motorik di otak. Sebenarnya banyak kelainan syaraf motorik yang terjadi di otak, tetapi tidak semua peristiwa tersebut dinamakan CP. Penyebutan CP memiliki karakteristik yaitu terjadinya pada masa perkembangan anak yaitu prenatal, natal, dan perinatal.

Menurut data dari World CP Day (Delembert \& Brosco, 2013) yang berlokasi di Australia terdapat banyak gejala secara fisik yang dialami anak dengan CP. Diantaranya mereka mencatat 1 dari 3 anak $\mathrm{CP}$ tidak bisa berjalan, 1 dari 4 anak CP tidak dapat berbicara, dan 3 dari 4 anak CP mengalami kesakitan, 1 dari 4 anak CP mengalami epilepsi, 1 dari 4 anak $\mathrm{CP}$ mengalami gangguan perilaku, 1 dari 2 anak CP mengalami gangguan intelektual, 1 dari 10 anak $\mathrm{CP}$ mengalami gangguan penglihatan, dan 1 dari 5 anak $\mathrm{CP}$ mengalami gangguan tidur.

Melihat data dan beberapa karakteristik yang menyertai anak CP menimbulkan kedukaan bagi orang tua, terutama ibu. Keadaan tersebut terlihat dari hasil asesmen yang dilakukan pada orang tua $\mathrm{CP}$ yang sering bertanya mengenai peluang kesembuhan bagi anaknya. Demikian halnya di jejaring sosial seperti group orang tua CP di grup Rumah Cerebral Palsy, Wahana Keluarga Cerebral Palsy, Yayasan Peduli Cerebral Palsy, maupun di jejaring facebook lainnya. Terlihat jelas bagaimana perasaan ibu dari anak CP, mereka sering bertanya "Bisakah anak saya berjalan?", "Bisakah anak saya disembuhkan?", "Apa yang harus dilakukan oleh ibu ketika anaknya sudah remaja?", "Bagaimana anak saya bisa berteman?", dan pertanyaan lain yang terkait. Dari pertanyaan-pertanyaan yang mengemuka di jejaring sosial tersebut sangat terlihat bahwa orang tua khususnya ibu sangat membutuhkan orang lain untuk diajak bercerita maupun berdiskusi mengenai kondisi anak mereka.

Ibu sosok yang berperan besar dalam perkembangan anak, terutama anak CP. Hampir di semua kehidupannya, anak CP membutuhkan orang lain untuk membantunya memenuhi kebutuhan hidupnya. Sosok ibu menjadi orang yang utama di mata anak CP. Oleh karena itu ibu harus mempersiapkan diri terlebih dahulu sebelum mendampingi anaknya. Termasuk juga mempersiapkan diri lebih matang untuk memahami kondisi psikologis ibu sendiri. Penelitian Manuel, et al. (2013) menyebutkan bahwa ibu yang memiliki

${ }^{1}$ Universitas Muhammadiyah Malang

\section{Korespondensi:}

Susanti Prasetyaningrum, Fakultas Psikologi Universitas Muhammadiyah Malang

Email: susanti@umm.ac.id 
anak CP lebih rentan untuk depresi. Dalam penelitian juga disebutkan bahwa ibu banyak melakukan penyesuaianpenyesuaian dalam hidupnya mulai dari menyesuaikan diri dengan karakteristik anak, penyesuaian emosi berupa reaksi emosional seperti malu, terkejut, stress, dan menyesuaikan pola pengasuhan dan perawatan pada anak.

Pendampingan bagi ibu dari remaja CP menjadi begitu penting, meskipun ibu telah menyesuaikan dengan kondisi anaknya tidak menutup kemungkinan ibu mulai mengalami kebingungan ketika anaknya menginjak remaja. Hal ini seperti dijelaskan diatas bahwa $\mathrm{CP}$ lebih pada hambatan dalam perkembangan motorik sehingga perkembangan yang lain seperti biologis, fisik, dan emosinya kemungkinan berkembang secara normal. Oleh karena itu orang tua perlu diberikan pendampingan berupa pemahaman terkait perkembangan remaja pada anak CP. Selain itu orang tua juga perlu memberikan keterampilan kepada remaja CP setidaknya untuk bertahan hidup di masa mendatang. Mengingat remaja $\mathrm{CP}$ ini semakin dewasa.

Pendampingan bagi ibu yang memiliki remaja $\mathrm{CP}$ dilakukan dengan mulanya menghadirkan ibu-ibu dalam sebuah kelompok. Alasan dibentuk kelompok adalah orang tua CP dapat saling memberikan manfaat bagi orang tua lain dengan berbagi informasi terkait $\mathrm{CP}$ ataupun saling menguatkan secara emosional satu sama lain. Group ini selain terdiri dari ibu-ibu dari remaja CP juga ada kalangan akademik yaitu mahasiswa maupun dari kalangan profesional seperti dokter, terapis, dan psikolog. Bentuk pendampingan ini yaitu diawali dengan asesmen, lalu dilanjutkan dengan metode sharing experience dan psikoedukasi.

\section{Metode}

Tujuan pendampingan ini untuk memberikan pemahaman terkait CP dan perkembangannya. Metode yang akan dilakukan adalah: 1) Sharing experience yang dibuat dalam kelompok-kelompok. Terdapat 3 kelompok yang terbentuk dan pada setiap kelompok terdapat 5-8 anggota kelompok. Kelompok terdiri dari ibu yang memiliki remaja $\mathrm{CP}$, mahasiswa, dokter, dan psikolog; 2) Psikoedukasi diberikan kepada ibu yang memiliki remaja $\mathrm{CP}$ dan significant others meliputi ayah, nenek, kakek, tante, atau saudara lainnya.

Pendampingan pada ibu-ibu yang memiliki anak cerebral palsy dilaksanakan selama 4 pertemuan. Pendampingan ini bertujuan untuk meningkatkan pemahaman ibu-ibu akan karakteristik, potensi, dan keadaan emosi anak cerebral palsy. Pendampingan pada ibu-ibu yang memiliki anak cerebral palsy terdiri dari dua kegiatan, yaitu sharing experience dan psikoedukasi.

Sharing experience diberikan sebanyak empat kali pertemuan dengan durasi waktu 60-90 menit setiap pertemuan. Anggota dari sharing experience ini adalah ibuibu yang memiliki anak cerebral palsy, pasien cerebral palsy yang memiliki tingkat keparahan kategori ringan, dan fasilitator. Partisipan yaitu ibu-ibu yang memiliki anak cerebral palsy berjumlah 23 orang dan pada sebelum serta sesudah mengikuti sharing experience, mereka mengisi skala yang telah disiapkan.
Tabel 1. Statistik Deskriptif Pre-test dan Post-test

\begin{tabular}{llll}
\hline & Range & Mean & SD \\
\hline Pre-test & $45-68$ & 63.48 & 10.757 \\
Post-test & $75-88$ & 82.43 & 3.906 \\
\hline
\end{tabular}

\section{Hasil}

\section{Hasil Analisis Kuantitatif}

Kategori Pemahaman Orang Tua Dalam asesmen awal, dari 23 partisipan, sebanyak 8 orang (35\%) memiliki pemahaman yang rendah, 11 orang (48\%) memiliki pemahaman yang sedang, dan 4 orang (17\%) memiliki pemahaman yang tinggi akan karakteristik, potensi, dan keadaan emosi anak cerebral palsy. Data tersebut digunakan sebagai acuan untuk memberikan pendampingan pada ibuibu yang memiliki anak cerebral palsy.

Setelah diberikan pendampingan dalam bentuk sharing experience dan psikoedukasi, dapat diketahui kebermanfaatan dari pendampingan tersebut. Berikut ini data kebermanfaatan pelaksanaan pendampingan secara keseluruhan.

Gambar 1 menunjukkan kebermanfaatan pendampingan yang berupa sharing experience dan psikoedukasi. Kebermanfaatan pendampingan bisa dilihat dari lima indikator yaitu materi, fasilitas, fasilitator, metode, dan kenyamanan dalam grup. Hasil tersebut menunjukkan bahwa menurut partisipan indikator yang paling tinggi menunjukkan kebermanfaatan pendampingan yaitu materi, kemudian diikuti oleh indikator kenyamanan dalam grup, fasilitator, fasilitas, dan metode.

Hasil analisa menunjukkan terjadi peningkatan skor pemahaman pada ibu-ibu yang mengikuti pendampingan. Peningkatan yang terjadi ditunjukkan dengan perbandingan skor pre-test dan post-test, yaitu mean pre-test sebesar 63.48 yang lebih rendah ketimbang post-test atau pasca pendampingan sebesar 82.43. Data tersebut menunjukkan bahwa terjadi peningkatan pada pemahaman ibu-ibu sebelum dan sesudah mengikuti pendampingan.

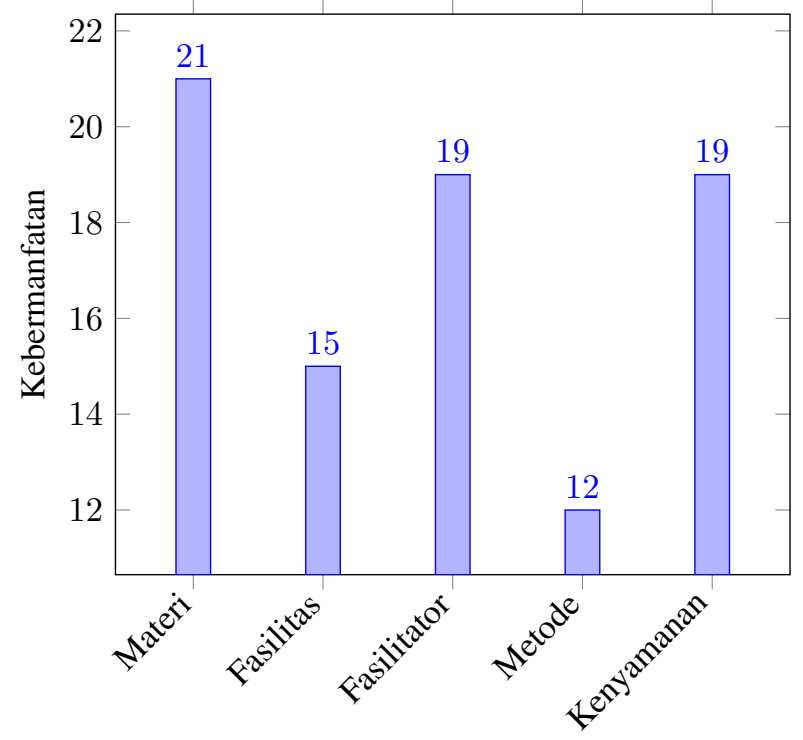

Gambar 1. Kebermanfatan pendampingan. 
Langkah berikutnya adalah melakukan uji signifikansi untuk mengetahui perbedaan setelah dan sesudah diberikan pendampingan. Hasil analisis menunjukkan ada perbedaan yang signifikan terkait pemahaman ibu yang memiliki anak cerebral palsy setelah pre-test dan post-test melalui pemberian pendampingan $(p<0.05)$.

\section{Hasil Analisis Kualitatif}

Hasil asesmen menunjukkan bagaimana tingkat pemahaman mereka tentang karakteristik, potensi, dan emosi anak cerebral palsy pada sebelum dan sesudah pendampingan. Berikut hasil data kualitatif pada masing-masing aspek pemahaman.

Karakteristik anak cerebral palsy. Pada pre-test, partisipan mengetahui bahwa anaknya berbeda dari anak-anak yang lain. Perbedaan itu mengacu pada adanya kerusakan/ cacat secara fisik yang sifatnya menetap. Rata-rata orang tua sudah mengetahui adanya tanda-tanda kerusakan itu sejak lahir. Dimulai dari organ tubuh yang gerakannya tidak terkontrol, kemudian terlambat perkembangannya (berjalan, bicara, lari, dsb).

Sementara pada post-test, Partisipan mulai mengetahui bahwa kerusakan/kelainan/gangguan pada anak CP bisa bersifat tunggal (satu macam) dan multi (lebih dari satu macam). Kerusakan tunggal atau multi tersebut tergantung pada keluasan kerusakan otak atau letak kerusakan di otak. Kemudian terjadi kekakuan/rigid pada gerakan otot sampai kekejangan otot, gangguan koordinasi dan keseimbangan, muncul gerakan-gerakan tidak disadari, dan tremor. Selain itu partisipan juga memahami bahwa ada karakteristik yang lebih penting disamping karakteristik fisik yaitu tingkat kecerdasan, kemampuan bicara, kemampuan mendengar, kemampuan penglihatan, karakteristik pada aspek taktil dan kinestetik, dan aspek persepsi.

Potensi anak cerebral palsy Berdasarkan pre-test, orang tua belum mengetahui bahwa ada anak-anak cerebral palsy yang memiliki potensi-potensi yang bisa dikembangkan. Namun menurut data post test, orang tua mulai memahami bahwa anak-anak cerebral palsy memiliki potensi yang bisa dikembangkan antara lain ada anak $\mathrm{CP}$ yang mampu menjadi guru dan memiliki banyak tulisan-tulisan bahkan ada yang sudah dicetak dalam bentuk buku atau novel. Selain itu ada juga yang memiliki potensi dalam melukis, dan bidang seni lain.

Keadaan emosi anak cerebral palsy. Sebelum pendampingan, Orang tua memiliki kebingungan untuk menghadapi anaknya yang terkadang sulit untuk dikontrol emosinya. Sedangkan saat post test orang tua merasa bahwa proses saling berbagi pengalaman dalam sesi sharing experience, membuat orang tua lebih memahami karakteristik emosi pada anak CP. Para orang tua juga berbagi cara untuk menghadapi anak CP yang susah mengontrol emosi dan ada beberapa orang tua meniru untuk menerapkan strategi yang sama.

\section{Diskusi}

Ibu-ibu yang memiliki anak berkebutuhan khusus sebagian besar akan membuat perubahan di dalam kehidupan sosial dan menyatakan perasaan frustasi dan ketidakpuasan yang tinggi. Roserbaum (2003) dalam penelitiannya menyebutkan bahwa orang tua anak $\mathrm{CP}$ mengalami kesedihan yang mendalam sehingga beberapa orang tua memerlukan konseling dan terapi. Oleh karena itu dapat disimpulkan bahwa sangat diperlukan pemberian pengetahuan akan karakteristik anak $\mathrm{CP}$, terutama yang menginjak remaja melalui pendampingan dengan sharing experience dan psikoedukasi.

Hasil pengabdian dengan model pendampingan pada ibu yang memiliki anak $\mathrm{CP}$, menunjukkan adanya peningkatan pemahaman ibu-ibu akan karakteristik, potensi, dan keadaan emosi anak cerebral palsy (CP). Selain itu dari hasil analisa juga menunjukkan adanya perbedaan yang signifikan terkait pemahaman ibu yang memiliki anak cerebral palsy setelah pre-test dan post-test melalui pemberian pendampingan Keefektifan sharing experience ini bukan saja berdasarkan hasil analisa, tetapi terlihat dari indikator kebermanfaatan yaitu indikator materi, fasilitas, fasilitator, metode penyampaian, dan kenyamanan dalam grup. Hasil tersebut menunjukkan bahwa menurut partisipan, indikator yang paling tinggi menunjukkan kebermanfaatan pendampingan yaitu materi, kenyamanan dalam group, fasilitator, fasilitas, dan metode.

Pendampingan yang diberikan kepada partisipan berupa pembentukan grup sharing experience. Menurut teori belajar sosial, sharing experiences dapat memunculkan daya inisiatif-motivasional bagi partisipan. Apalagi jika yang menjadi partisipan tersebut adalah orang yang memiliki pengalaman akan hal yang di bagikan, serta termasuk yang membutuhkan informasi itu. Pada pelaksanaannya, dalam grup ibu-ibu yang memiliki anak CP bisa menceritakan pengalaman saat pertama kali mengetahui anaknya terdiagnosa $\mathrm{CP}$, kemudian bagaimana anggota keluarga saling memberikan dukungan, mulai mencari informasi terkait $\mathrm{CP}$, bahkan pengalaman mencari sekolah. Di dalam grup juga terjadi proses belajar dimana antar anggota berbagi cara memahami karakteristik emosi dan perilaku anak CP.

Grup sharing experience juga memiliki anggota dari dokter dan psikolog. Dokter memberikan pengetahuan secara lebih sederhana dalam memahami cerebral palsy. Materi yang diberikan terkait CP yaitu adanya cedera otak atau masalah perkembangan otak. Penyebab ini mempengaruhi kecacatan yang berlangsung sejak anak-anak sehingga menyebabkan gerakan reflek. Masalah-masalah yang berkaitan dengan cedera ini juga dibahas antara lain masalah intelektual, kejang, penglihatan, dan pendengaran. Kemudian psikolog memberikan materi terkait karakteristik emosi remaja CP. Fokus dari emosi remaja yang mengalami $\mathrm{CP}$ lebih ke arah kecenderungan untuk memiliki konsep diri negatif karena merasa tidak percaya diri dan merasa berbeda dengan teman-temannya yang normal. Dengan pemberian materi itu, partisipan memiliki pengetahuan tentang CP.

Partisipan sharing experiences mampu memahami karakteristik remaja $\mathrm{CP}$ melalui diskusi yang ada di dalam grup tersebut. Jika melihat indikator yang paling menyumbangkan kebermanfaatan yaitu kenyamanan dalam group, maka dapat disimpulkan bahwa di dalam grup itu muncul dinamika kelompok. Masing-masing anggota saling menceritakan dan berdiskusi. Menurut penelitian yang dilakukan oleh Barnes \& Dia (2008), orang tua yang memiliki anak berkebutuhan 
khusus akan memunculkan penerimaan terhadap kondisi anaknya apabila mendapatkan pemahaman tentang kondisi anaknya. Dalam program ini ditunjukkan bahwa akan lebih mudah orang tua menerima kondisi anaknya apabila mereka berada pada suatu kelompok dimana anggotanya memiliki pengalaman yang sama.

\section{Kesimpulan}

Berdasar data empirik yang telah dikumpul dan dianalisa, pendampingan yang diberikan terbukti efektif untuk meningkatkan pemahaman ibu-ibu yang memiliki anak cerebral palsy (CP) akan karakteristik, potensi, dan keadaan emosi anak cerebral palsy. Efektifitas juga bisa dilihat dari indikator persepsi kebermanfaatan pendampingan (sharing experiences dan psikoedukasi) yaitu materi, fasilitas, fasilitator, metode, dan kenyamanan dalam group.

Implikasi dari pendampingan ini bagi partisipan, bahwa sharing experience ini bisa dilakukan secara lebih teratur dari segi pelaksanaannya karena sangat bermanfaat bagi partisipan. Selain itu dari sesi pelaksanaan perlu ditambahkan lagi termasuk feedback harus dirancang secara lebih lengkap dan efektif.

\section{Referensi}

Barnes, S. L. N., \& Dia, D. A. (2008). Families of children with disabilities: A review of literature and recommendations for interventions. Journal of early and intensive behavior intervention, 5, (3), 93-107.

Delembert, G., \& Brosco, J. P. (2013). Do politics affect prevalence? An overview and the case of cerebral palsy, Journal of Developmental \& Behavioral Pediatrics, 34 , (5), 369.

Delphie, B. (2006). Pembelajaran anak tunagrahita. Bandung: Refika Aditama.

Dorland. (2005). Kamus kedokteran Dorland. Edisi 29. Jakarta: EGC.

Manuel, J., Naughton, M. J., Balkrishman, R., \& Koman, L.A. (2013). Stress and adaptation in mothers of children with cerebral palsy. Journal of Pediatric Psychology, 28, (3).

Rosenbaum, p. (2003). cerebral palsy: what parents and doctors want to know. Mc Master University, Hamilton, ON, Canada: BMJ (326) 3 May 2003.

Soetomenggolo, T.S., \& Ismael, S. (1999). Asfiksia dan trauma perinatal. Neurologi Anak. edisi Pertama. Jakarta: BP IDAI. 